\title{
A REVIEW OF HALOCORYZA ALLUAUD, WITH NOTES ON ITS RELATIONSHIP TO SCHIZOGENIUS PUTZEYS (COLEOPTERA: CARABIDAE).
}

\author{
By Donald R. Whitehead \\ Department of Entomology, University of Alberta
}

\section{INTRODUCTION}

My work on a revision of Nearctic species of the scaritine genus Schizogenius Putzeys has brought to light two species, one of them new, that properly belong to the otherwise African Halocoryza Alluaud. The major purposes of this paper are to help clarify the taxonomy of Halocoryza, to describe the American species, and to contrast the genus against Schizogenius. Halocoryza is poorly known and apparently very rare in collections. Despite this limitation, however, I think some interesting zoogeographic and phylogenetic points emerge. These are considered briefly, following the taxonomic treatment.

Halocoryza and Schizogenius belong to the "tribe" Clivinini (sensu Jeannel, 1946), within which they may be recognized by having a bi- or trituberculate clypeal margin (the antero-lateral angles angulate but not tuberculate), along with four to six pairs of nearly parallel longitudinal ridges between the eyes. In the closely related Lophocoryza Alluaud, the clypeal margin is quadrituberculate and the paired frontal carinae are reduced, the outer pairs short and oblique. At least one other genus, Coryza Putzeys, should probably be placed in the same group; but it is only distantly related, and lacks paired ridges on the frons.

Ball's ( 1960) key to North American scaritine genera, as modified by the substitution of couplet 3(I) below, can be used to distinguish Schizogenius and Halocoryza from all other Scaritini of the world. 3(I). Frons with four to six pairs of longitudinally directed carinae between eyes, AND clypeus bi- or trituberculate along anterior margin 3A.

Frons with two deep grooves, or with shallow, transverse or oblique grooves, but without a series of parallel carinae (North America); OR, if frons with four or more pairs of nearly parallel longitudinal carinae between eyes, clypeus without tubercles along anterior margin (World) ........ 4 . 


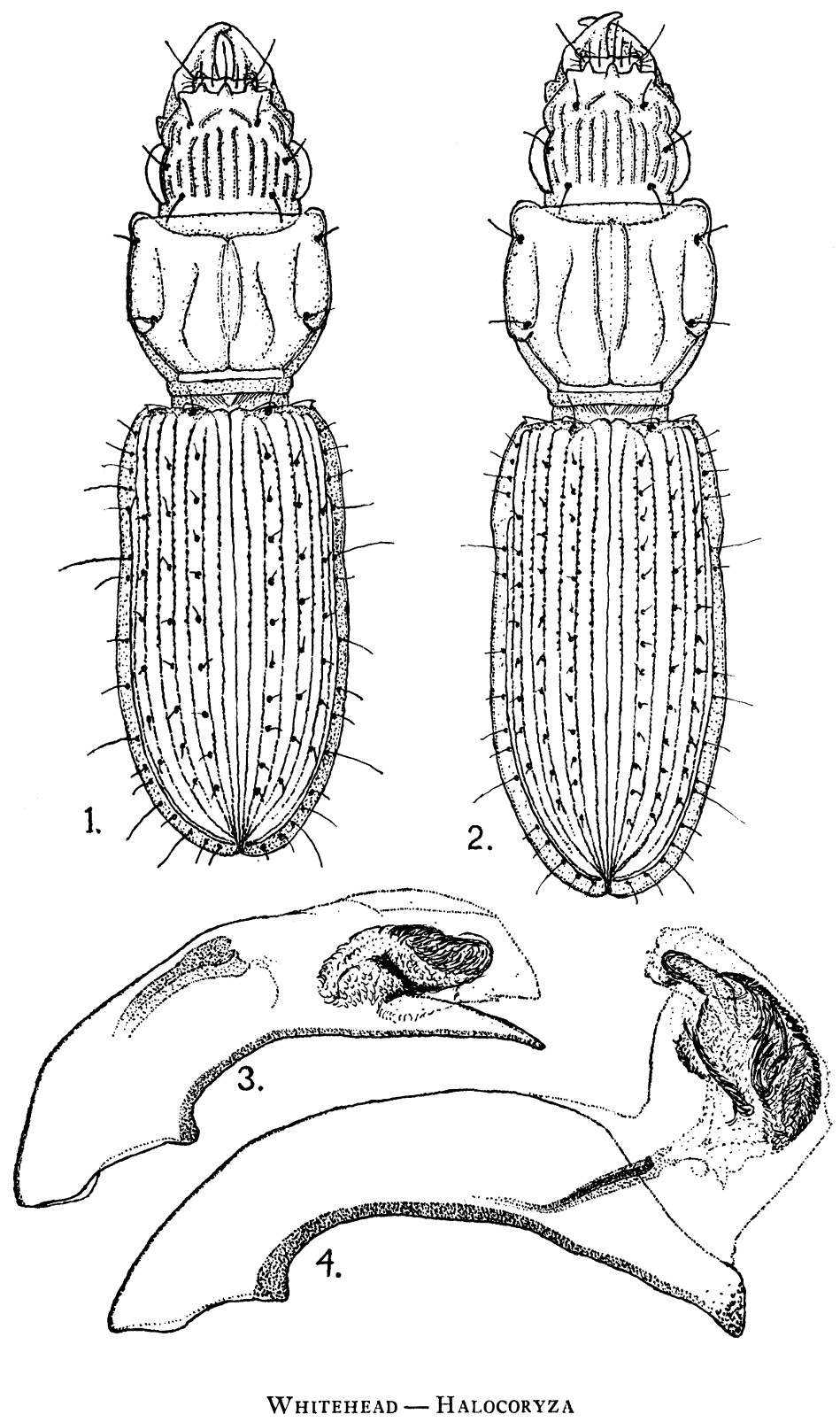


$3 A(3)$. Small beetles, length of elytra less than $1.50 \mathrm{~mm}$.; second article of antenna plurisetose; pygidium without a series of fine paramedian longitudinal striae

Halocoryza.

Larger beetles, length of elytra more than $\mathrm{I} .65 \mathrm{~mm}$.; second article of antenna at most bisetose; pygidium bearing a series of fine paramedian longitudinal "striae" (actually rows of small tubercles, possibly used for stridulation)

Schizogenius.

The most diagnostic characters of Halocoryza are the nonstriate pygidium and the plurisetose second antennal article. But many additional characters may be used to separate the genus from Schizogenius, including the following. I. Mandibles prominent, nearly straight laterally, abruptly bent near apices. 2. Lacinia without setae along outer margin. 3. Frontal carinae almost perfectly regular, parallel, equidistant, and equally raised, the frons appearing evenly convex. 4. Neck not pitted or punctate dorsally, and not extended along posterior margin of eyes. 5. Eyes reduced, and bordered dorsally by a distinct carina. 6. Gula broad, at narrowest point more than 0.4 maximum width of mentum. 7. Mentum not deeply emarginate at middle, with median tooth obsolete, and with the epilobes reduced. 8. Tarsi short, the hind leg with tarsus less than 0.6 length of tibia. 9. Paramedian carinae of second abdominal sternum short, widely spaced and usually weakly developed. IO. Median lobe of male genitalia neither arcuate nor abruptly deflexed in apical third.

Although Halocoryza and Schizogenius are very similar, their separation is justifiable for several reasons. Morphologically, the division results in two unequal but reasonably homogeneous groups. (Schizogenius could be further split into perhaps four genera, but I think subgenera would be better). The limited available biological evidence suggests that the species of Halocoryza are probably all inhabitants of the coast, whereas the species of Schizogenius live in non-saline habitats. Also, their distribution patterns are best interpreted if they are treated as separate genera.

Measurements were made with an eyepiece micrometer mounted in a Leitz stereoscopic microscope at I50 magnifications, as follows: total length (TL), represented as the sum of the head length from

Explanation of Plate 15

Fig. 1. Body of H. acapulcana (dorsal view).

Fig. 2. Same for $H$. arenaria.

Fig. 3. Median lobe of male genitalia of $H$. acapulcana (lateral view).

Fig. 4. Same for $H$. arenaria (but internal sac everted). 
base of eye to antero-lateral angle of clypeus, plus pronotal length (LP) along midline, plus length of left elytron (LE, the most convenient indication of size) along suture; maximum width of head (WH) across eyes; minimum width of frons (WF) between eyes; maximum width of pronotum (WP); maximum width across both elytra (WE); length of hind tarsus ( $\mathrm{Ta}$ ), excluding claws; length of hind tibia ( $\mathrm{Ti}_{\mathrm{i}}$; and length of median lobe (LA) from the dorsal margin of the basal orifice to the apex. Figures I and 2 were drawn with the aid of a camera lucida, figures 3 and 4 with an ocular grid.

\section{Halocoryza Alluaud}

Halocoryza Alluaud 1919:100. Type species, Halocoryza maindroni Alluaud 1919:101, type by monotypy. Csiki 1927:547. Jeannel 1946:228. Vinson 1956: 313.

Very small beetles (LE, I.I5-I.5O mm.); form elongate, cylindrical. Color testaceus, without metallic luster. Integument dull, with isodiametric microsculpture extensively distributed, especially conspicuous on the prothoracic pleura, abdominal sterna, and all frontal interspaces of head.

Head. Labrum slightly emarginate to biemarginate; dorsal surface with seven setae in front, the median and two outer ones longest; labrum margined laterally with four to six pairs of frayed or serrated setae, the most anterior two or three pairs curved forward and inward over mandibles. Clypeus with three subequal tuberculate teeth, the median tooth rising distinctly above plane of clypeus; paramedian carinae short and oblique, ending before reaching median tubercle; median field triangular, at base more than I.5 greatest width of median frontal sulcus; clypeus with one pair of setae, located basally and lateral to the carinae. Clypeal suture obsolete. Frontal lobes reduced, oblique. Frons with six pairs of longitudinally directed carinae between eyes, the four median pairs very nearly straight, parallel, equidistant, equally raised, narrow and sharp throughout (the frons thus quite evenly convex in appearance); median sulcus smooth, with no trace of a median carina; carina five well developed, slightly oblique; carina six well developed, forming a distinct dorsal margin to eye, either virtually continuous (in American species) or broken on frontal lobe. Anterior supraorbital seta placed immediately in front of fifth frontal carina; posterior seta placed behind fourth carina (American species) or behind interspace between fourth and fifth carinae. Eyes reduced (WF/WH more than o.75), coarsely faceted. Neck impunctate, not extended along posterior margin of eyes. Antennae with articles five to ten square or slightly transverse, 
distinctly moniliform; scape with a single subapical dorsal seta; pedicel plurisetose; articles three to eleven pubescent. Mandibles moderately elongate and prominent, nearly straight along lateral margin, abruptly bent at tips; inner ventral margin of right mandible with a small tooth near middle; scrobe oblique. Terminal article of maxillary palpus strongly swollen basally, and with a basal fan of five or six fine, appressed bristles. Lacinia with apex acute, abruptly bent, and preceded on inner margin by a series of stout setae; outer margin of lacinia lacking setae. Penultimate article of labial palpus bisetose; terminal article with a basal fan of two fine, appressed bristles. Mentum not deeply emarginate at middle, with median tooth nearly or quite obsolete, and with epilobes reduced; mentum with a paramedian and a postero-lateral seta on each side, and with a pair of large pouch-like basal sensory pits. Submentum with one paramedian and one paralateral pair of setae. Gula broad, its narrowest part more than 0.4 width of mentum.

Thorax. Pronotum usually slightly transverse, with both paramedian and paralateral longitudinal sulci (not strongly developed in American species); median sulcus closely bordered by a pair of carinae, except at base (American species only); anterior and posterior pairs of marginal setae present, posterior pair recessed from margin and situated at or near base of paralateral sulcus. Prosternum strongly compressed between coxae, broadened and convex behind where lacking setigerous punctures. Metepisternum slender, elongate.

Elytra. Lateral channel slightly narrowed at apex, shallow, lacking subapical pits; umbilicate series of punctures unbroken. Disc of elytra with at least six setae on intervals three, five, and seven; in addition, interval three has a long, whip-like seta at base. Intervals one to seven subequal, slightly convex; interval eight narrow, carinate apically, and parallel to elytral margin. Striae finely punctate in at least basal half.

Hind wings fully developed, probably functional.

Legs. Front tibiae with four well developed external teeth; apical and subapical spurs short, subequal; ventral-basal margin with three setae. Front and middle tarsi narrow and nearly glabrous in both sexes. Tarsi short $(\mathrm{Ta} / \mathrm{Ti}$ less than 0.6$)$. Paronychia subequal in length to tarsal claws.

Abdomen. One pair of paramedian ambulatory setae on sterna three to six in both sexes; two pairs of equidistant apical marginal setae on sternum six. Second sternum with a pair of straight, short, oblique, widely separated, often inconspicuous paramedian carinae. Sterna four to six each with a well developed transverse suture. 
Pygidium with two paramedian setae and one large paralateral seta on each side, plus a variable number of microsetae; fine median longitudinal striae lacking; margin of pygidium entire in both sexes.

Male genitalia. Parameres subequal, slightly asymmetric, slender, with one to three setae near apex. Median lobe nearly symmetric; base non-lobate; median lobe not markedly constricted sub-basally; apical third neither compressed nor strongly bent downward, the apex strongly produced in American species. Internal sac doubly invaginated (or telescoped), with a pair of basal sclerites of variable form; apical brush lacking conspicuous spines, sclerites, or setae (American species) or with a large number of dorso-apical seta-like scales.

Immature stages. See Vinson (1956).

KEY TO THE SPECIES OF HALOCORYZA

I. Pronotum without submedian carinae; basal diameter of median lobe of male genitalia more than 0.65 ventral length, apex not produced. Old World ........... maindroni, jeanneli.

Pronotum with submedian longitudinal carinae; basal diameter of median lobe of male genitalia less than 0.65 ventral length, apex more or less produced. New World

2( I). Smaller species (LE, I.2O-I.35 mm.); pale testaceus; pronotum distinctly transverse (LP/WP less than 0.95 ); pronotal carinae weakly developed, separated by less than o.I WP; elytra sparsely setose, interval three with Io or fewer setae; basal diameter of median lobe of male genitalia more than 0.5 ventral length, apex of median lobe acute in lateral view. Pacific coast of Mexico acapulcana.

Larger species (LE, I.35-I.45 mm.) ; dark testaceus; pronotum not distinctly transverse (LP/WP more than 0.95 ); pronotal carinae sharply raised and separated by more than o.I WP; elytra densely setose, interval three with more than IO setae; basal diameter of median lobe of male genitalia less than 0.5 ventral length, apex of median lobe broadly truncate. West Indies arenaria.

Halocoryza acapulcana Whitehead, new species

This is the only Halocoryza so far known from North America. From the West Indian $H$. arenaria, it is readily distinguished by its smaller size, more transverse pronotum, less sharply elevated and 
more closely placed pronotal carinae, and by details of the male genitalia. See fig. I.

Holotype male. "Acapulco, Gro., Mex. Aug. I8, I938 Lipovsky" and "Museum of Comparative Zoology". To be deposited in the Museum of Comparative Zoology, M. C. Z. Type No. 3 I, 68.

With the characters of the genus; color pale testaceus. Sixth frontal carina of head extended unbroken onto frontal lobe. Eyes small ( WF $/ \mathrm{WH}$, o.8o), flat, coarsely faceted, the facets all equal in size. Posterior supraorbital seta placed behind and nearly in line with the abbreviated fourth frontal carina. Lacinia appearing quadridentate, the abruptly bent apex preceded in line by three pairs of stout crossed setae. Gula at narrowest point approximately 0.48 width of mentum. Pronotum slightly transverse (LP/WP, o.89). Paramedian and paralateral sulci shallow, inconspicuous. Median sulcus, except basally, closely bordered by a pair of weak carinae which are convergent both apically and basally; interspace at widest point less than o.Io WP. Antcrior transverse impression impunctate. Elytral interval three with nine or Io regularly spaced setigerous punctures near midline. Intervals five and seven with six to eight setigerous punctures placed near the inner striae. Penultimate tooth of front tibia with seta submedian. Tarsi very short ( $\mathrm{Ta} / \mathrm{Ti}, 0.56)$. Sternum two with paramedian carinae poorly developed and inconspicuous. Median lobe of male genitalia (fig. 3) with apex strongly produced and very acute in lateral view; basal diameter of median lobe 0.55 ventral length. Internal sac with elongate basal sclerites, otherwise lacking distinct sclerites or spines; apical brush large but not heavily sclerotized, lacking enlarged seta-like plates dorso-apically.

Measurements. TL, I.96 mm. LE, I.20 mm. WH, $0.42 \mathrm{~mm}$. WE, $0.66 \mathrm{~mm}$. LA, O.4I mm.

Allotype female. With the same label data as the holotype, to be deposited in the Museum of Comparative Zoology. This specimen differs in no significant way from the male, except for the genitalia (not examined).

Paratypes. Three males and thirteen females with the same label data as the holotype, to be distributed as follows: G. E. Ball ( I female); British Museum of Natural History (I female) ; California Academy of Sciences (I female); Institut Royal des Sciences Naturelles de Belgique ( I female); Museum of Comparative Zoology ( 2 males, 5 females); Jacques Nègre (I female); United States National Museum ( I female); D. R. Whitehead (I male, 2 females).

Variation. No important variation except size was observed: LE, 
I.2O-I.35 mm.; mean (I7 exx.) I.3O mm. Body proportions are quite constant: LP/WP, o.88-0.9I; WF/WH, o.76-o.8o.

Distribution. H. acapulcana is known only from the type series and one additional, dissected specimen from Acapulco, Guerrero, Mexico. Its name is derived from the type locality. Although no specific data are available, acapulcana is very probably an inhabitant of the coast, and may be intertidal.

\section{Halocoryza arenaria (Darlington), new combination}

Schizogenius arenarius Darlington 1939:84. Type locality - Rio Yaque del Sur, near Barahona, Dominican Republic; holotype in the Museum of Comparative Zoology, M. C. $Z$. Type No. 23,505, examined. Blackwelder 1944:27.

With the characters of the genus (see fig. 2) ; color dark testaceus. Larger than $H$. acapulcana-LE, I.35-I.45 mm.; mean (5 exx.), I.39 mm. Sixth frontal carina of head extended unbroken onto frontal lobe. Eyes small (WF/WH, o.76-o.8o), flat, coarsely faceted, the facets all equal in size. Posterior supraorbital seta placed behind and nearly in line with the abbreviated fourth frontal carina. Lacinia appearing quadridentate, the abruptly bent apex preceded in line by three pairs of stout, crossed setae. Gula at narrowest point approximately 0.48 width of mentum. Pronotum usually slightly elongate (LP/WP, 0.97-I.06). Paramedian and paralateral sulci shallow, but not as inconspicuous as in acapulcana. Median sulcus, except basally, closely bordered by a pair of sharply elevated carinae which are most widely separated just before apex; interspace at widest point more than 0.Io WP. Anterior transverse impression faintly punctate. Elytral interval three with twelve or thirteen regularly spaced setigerous punctures placed near the inner striae. Penultimate tooth of front tibia with seta submedian. Tarsi very short $(\mathrm{Ta} / \mathrm{Ti}$, approximately 0.55$)$. Sternum two with paramedian carinae usually well developed. Median lobe of male genitalia (fig. 4) with apex strongly produced, broadly truncate in lateral view; basal diameter of median lobe 0.4I ventral length. Internal sac with elongate basal sclerites, otherwise lacking distinct sclerites or spines; apical brush large but not heavily sclerotized, lacking enlarged seta-like plates dorso-apically.

Distribution. I have seen six specimens of $H$. arenaria, from two localities in the West Indies: Barahona, Dominican Republic (Holotype) ; and Rio Piedras, Puerto Rico (one male and three females in the Museum of Comparative Zoology, and one female in my collection). In addition, one other specimen from the same 
Puerto Rican locality is in the British Museum (Natural History). Both known localities are coastal, and arenaria is probably an inhabitant of the sea-shore as seems characteristic for the genus. Darlington (1939) recorded his unique specimen as having been taken ". . . under a deeply buried $\log$ on the sandy ocean beach ..." He recognized many of its essential features and (in litt.) suggested to me its probable relationship to Halocoryza.

\section{DISCUSSION}

As noted in the generic description, Old World species of Halocoryza differ from New World species in at least the following respects: pronotum lacking submedian carinae; sixth frontal carina broken in front of eye; and apex of median lobe of male genitalia not produced, the basal diameter more than 0.65 ventral length. Once the genus is better known, it may be desirable to place the American species in a separate subgenus.

Mr. Jacques Nègre (in litt.) has confirmed my impression that Jeannel's (1946) description and figures of maindroni are very inaccurate and misleading. The type specimen and other examples in the Muséum National d'Historie Naturelle, Paris (including Madagascar material) resemble and may be conspecific with the Arabian specimen of maindroni seen by me, and are generally in accord with Alluaud's (1919) original description and figures. Vinson (1956) described $H$. jeanneli from Mauritius in comparison with Jeannel's interpretation of maindroni; his study seems accurate in detail, and may portray the true maindroni. I suspect that these species may be identical, since they should have a high tolerance to salinity and desiccation and hence be able to disperse easily over sea barriers. However, it is quite possible that the populations on both Mauritius and Madagascar are endemics distinct from the mainland populations.

If they do disperse readily, the species of Halocoryza should be widespread. However, the scanty available information indicates that the present day distribution, though equatorial, is apparently not pantropical. Only acapulcana is so far known from continental North America, but arenaria may yet be found on the Atlantic coast. The African species (maindroni, jeanneli) are found along the east coast north to Arabia (Britton, I948) and on islands in the Indian Ocean. Although no South American or West African species are known, at least a past occurrence in both areas must be assumed to account for the present distribution of the genus.

Available evidence suggests dispersal from Africa, the most probable center of origin. The Atlantic was probably crossed by "rafting" 
(Darlington, 1957), using the equatorial Atlantic currents. I think Halocoryza is unlikely to travel long distances by air, but part of the trip could have been made in this way. If so, a raft should presumably have the same catching effect as an island. Regardless of the mode of travel, however, the carabid faunas of mid-Atlantic islands are of predominantly Old World origin (e.g., Lindroth, 1960; Wollaston, I865).

The relationships of Halocoryza further indicate an African origin. Its closest relative is the American Schizogenius (which is probably derivative or at least shared a direct common ancestor with Halocoryza), but no other related genera occur in the Americas. In Africa, the nearest relative is Lophocoryza, a relict and certainly non-derivative genus. The Indo-African genus Coryza is distantly related and seems to link Halocoryza and Lophocoryza with other Old World clivinine genera.

The origin of Schizogenius from an early invasion of the Americas by some Lophocoryza-Halocoryza stock, followed by a secondary invasion of Halocoryza, can readily be explained by the "taxon-cycle" mechanisms outlined by Wilson ( I96r). However, it seems unlikely that multiple trans-Atlantic migrations have taken place, even though Halocoryza is a relatively good candidate for such crossings. No irreversible characters of the genus conclusively demonstrate an indirect relationship with Schizogenius. Moreover, some characters of Halocoryza are found, I think primitively, in some Schizogenius (abbreviated paramedian clypeal carinae; paralateral pronotal sulci; paramedian ambulatory setae on sternum six in both sexes; short hind tarsi; moniliform antennae; and elytral intervals three, five, and seven with setigerous punctures).

Therefore, an alternative proposal merits mention. If but a single invasion occurred, it would follow that modern Halocoryza was directly ancestral to Schizogenius. The model for such direct ancestry is simple. Halocoryza at the time of invasion could have been no more different from extant Old and New World species than the latter now are from each other, and must have had the same adaptations for a seaside habitat then as now. One would not expect a rapid rate of evolution in a group of widespread species well adapted to a stable environment. That is, Halocoryza may be considered as an escapee from a changing environment (Maslin, 1952). But populations entering the quite different inland and freshwater habitats would have been forced to acquire new physiological adaptations at an accelerated rate. These new adaptations were doubtless accompanied by the physical modifications now found in Schizogenius, 
which can thus be considered as both a contemporary and as a descendant of Halocoryza.

\section{Acknowledgements}

I am indebted to Dr. Philip J. Darlington, Jr. (Museum of Comparative Zoology) for the loan of the material used in this study. I am further grateful to him for his courtesy during my visits to the Museum, and for a number of useful suggestions.

Mr. Jacques Nègre (Versailles, France) has most obligingly checked material in the Muséum National d'Historie Naturelle in Paris at my request, thus providing a wealth of useful information.

I wish to thank Dr. George E. Ball and Mr. John R. Barron (University of Alberta) for reading and criticising the manuscript. This study was financed in part by National Science Foundation Grant GB33I2, held by Dr. Ball.

\section{Literature Cited}

Alluaud, C.

1919. Contributions à l'étude des Carabiques d'Afrique et de Madagascar [Col.] XXIII. Observations sur divers Clivinides; descriptions d'une race, d'une espèce et d'un genre nouveaux. Bull. Soc. ent. Fr. 1919: 99-102.

BALL, G. E.

1960. Carabidae (Latreille, 1810). Fascicle 4, pp. 55-174. In R. H. Arnett. 1960. The beetles of the United States. Catholic University of America Press, Washington.

BLACKWELDER, R. E.

1944. Checklist of the coleopterous insects of Mexico, Central America, the West Indies, and South America. Part 1. Bull. U. S. nat. Mus. 185: xii + pp. 1-188.

BRITTON, E. B.

1948. Coleoptera: Cicindelidae and Carabidae. British Museum (Natural History) Expedition to South-West Arabia 1937-8. 1: 87-131,

Csiki, E. plates VII-IX.

1927. Carabidae: Carabinae II. Pars 92, Vol. 1, pp. 315-622. In S. Schenkling. Coleopterorum Catalogus. W. Junk, Berlin.

Darlington, P. J., JR.

1939. West Indian Carabidae V. New forms from the Dominican Republic and Puerto Rico. Mem. Soc. cubana Hist. nat. 13: 79-101.

1957. Zoogeography. John Wiley and Sons, Inc., New York. xi +675 JEANNEL, $R$. pp.

1946. Coléoptères carabiques de la region malgache (première partie). Faune de l'Empire française 6: 372 . 
LINDROTH, C. H.

1960. The ground-beetles of the Azores (Coleoptera: Carabidae) with some reflexions on over-seas dispersal. Bol. Mus. municipal Funchal 1960 (13) : 5-48.

MasLin, T. P.

1952. Morphological criteria of phylogenetic relationships. Systematic Vinson, J. Zool. 1: 49-70.

1956. A new scaritine beetle from Mauritius. Mauritius Inst. Bull. 3: $313-316$.

WILson, E. O.

1961. The nature of the taxon cycle in the Melanesian ant fauna. Amer. Nat. 95: 169-193.

Wollaston, T. V.

1865. Coleoptera atlantidum, being an enumeration of the coleopterous insects of the Madeiras, Salvages, and Canaries. John Van Voorst, London. xlvii $+526+140 \mathrm{pp}$. 

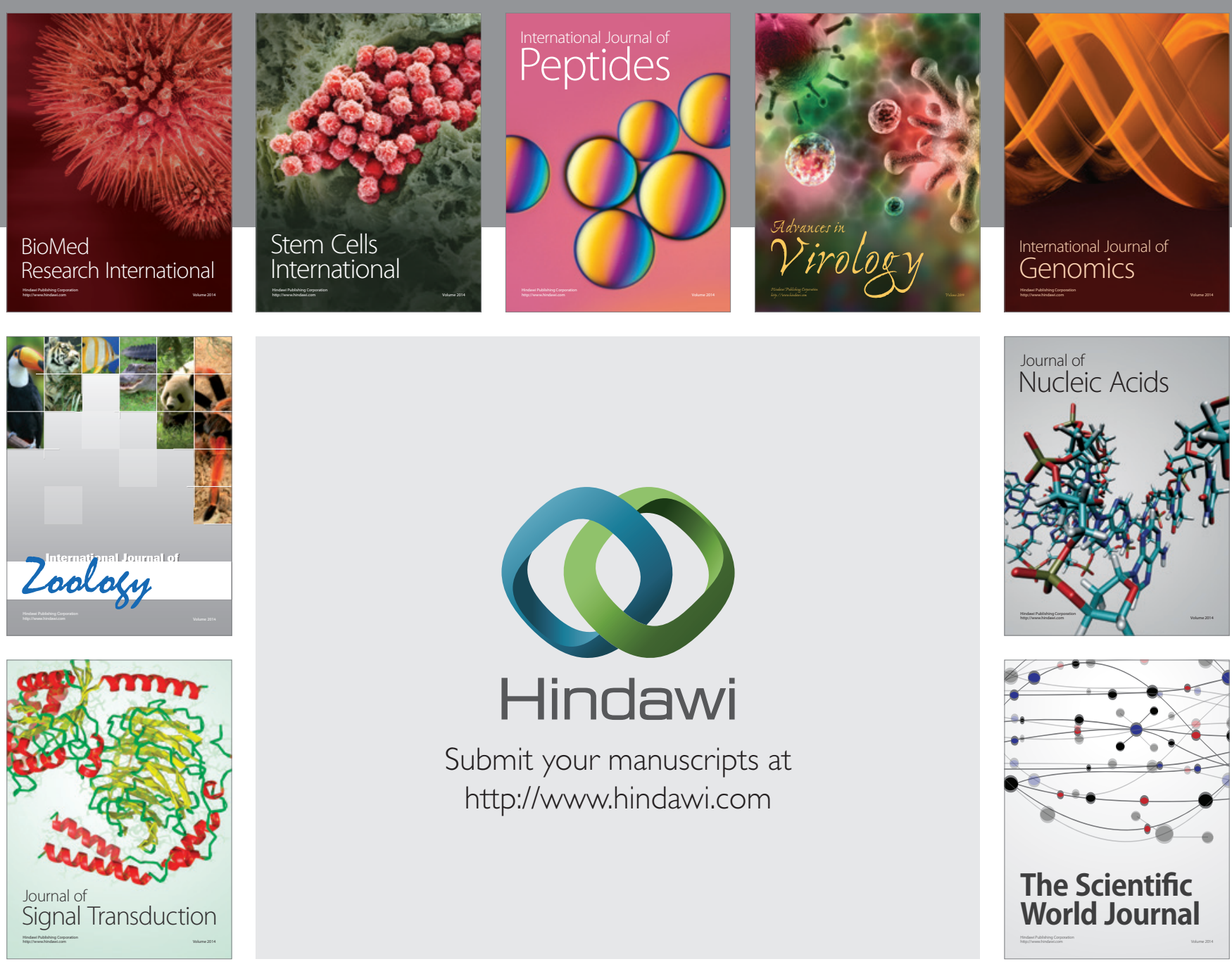

Submit your manuscripts at

http://www.hindawi.com
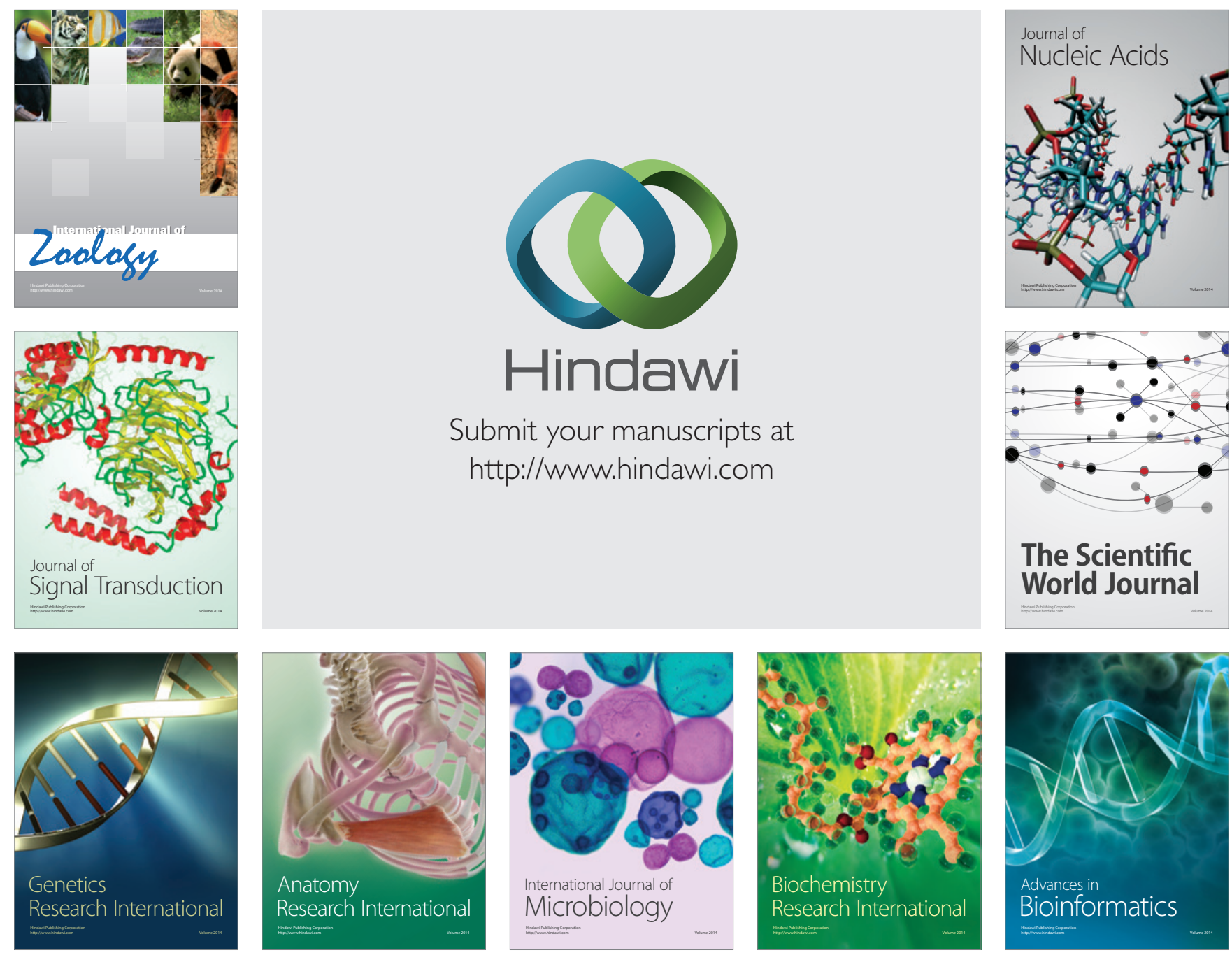

The Scientific World Journal
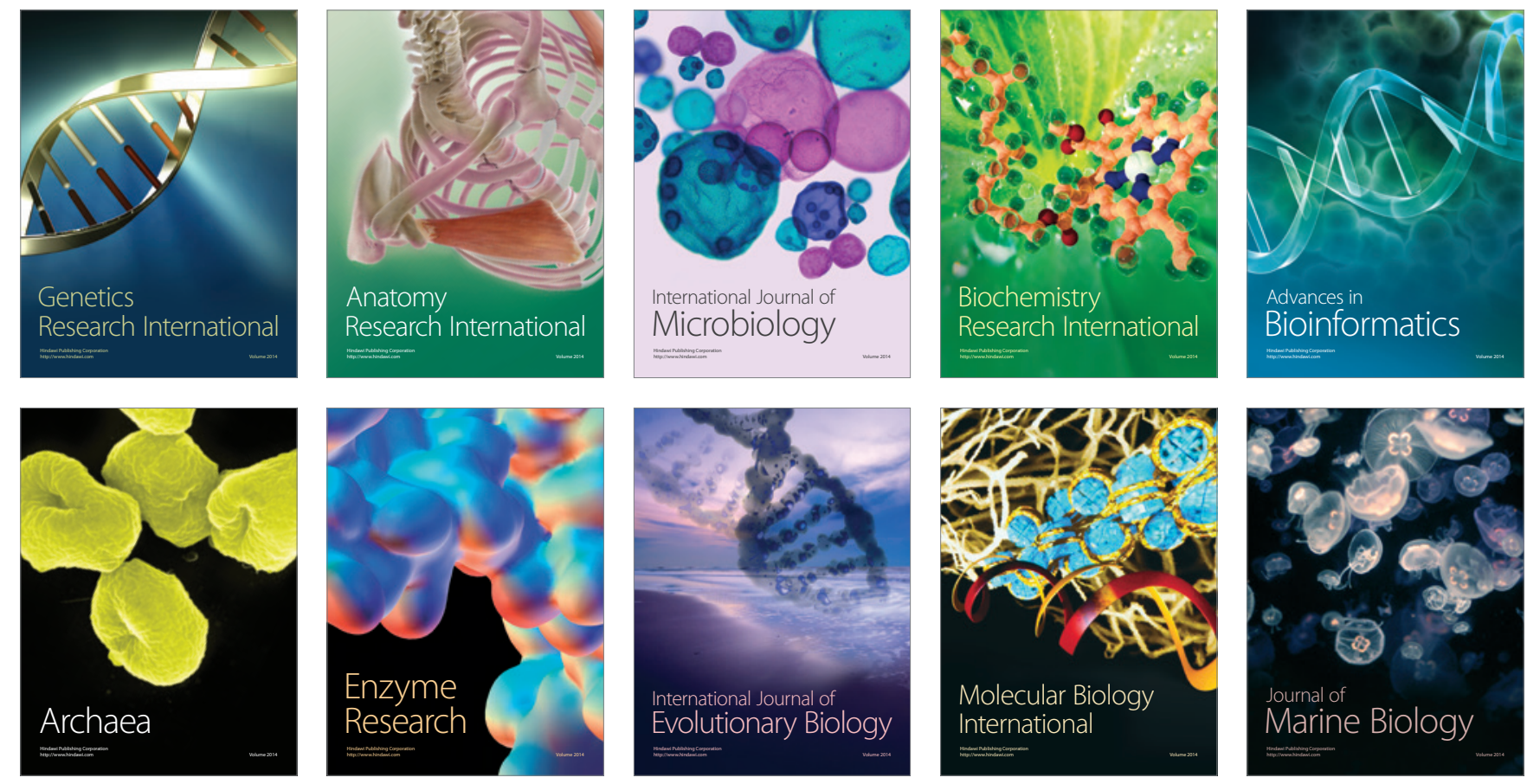